\title{
Hepatotoksisitas pada Anak Penderita Human Immunodeficiency Virus di Rumah Sakit Hasan Sadikin Bandung
}

Lidiyasiska, Adi Utomo Suardi, Anggraini Alam

Bagian Ilmu Kesehatan Anak Fakultas Kedokteran Universitas Padjadjaran/RSUP Dr. Hasan Sadikin, Bandung

Latar belakang. Gangguan hati merupakan masalah pada pasien HIV. Sebagian besar pasien HIV dengan gangguan hati tidak menunjukkan gejala sehingga gangguan hati baru diketahui saat pemeriksaan enzim hati.

Tujuan. Mengetahui prevalensi dan faktor yang berhubungan dengan hepatotoksisitas pada anak pasien HIV di Rumah Sakit Hasan Sadikin Bandung

Metode. Metode penelitian adalah deskriptif analitik dengan rancangan potong lintang. Subjek penelitian berjumlah 52 anak HIV. Dilakukan pengambilan data demografis, antropometri serta pemeriksaan CD4 dengan metode flow cytometri, SGOT dan SGPT dengan metode spektrofotometri UV dengan pyridoxal-5-phosphate. Data yang didapat kemudian dianalisis dengan uji chi square, Fisher exact dan Mann Whitney.

Hasil. Usia rata-rata pasien pada penelitian ini yaitu 8,2 $\pm 3,5$ tahun. Dua puluh delapan (54\%) subjek penelitian berjenis kelamin laki-laki. Kadar median SGOT, yaitu 28 U/L (15-49 U/L) dan median SGPT yaitu 21 U/L (6-47 U/L). Sebanyak 7 Anak (14\%) subjek penelitian didapatkan hepatotoksisitas ringan dengan nilai fungsi hati 1,25-2,5 kali batas atas normal. Faktor yang berhubungan dengan hepatotoksisitas tidak berbeda bermakna.

Kesimpulan. Pada anak pasien HIV didapatkan angka kejadian gangguan fungsi hati 14\%. Tidak terdapat hubungan kejadian hepatotoksisitas dengan faktor lama terapi antiretroviral, stadium klinis, derajat imunodefisiensi, jenis antiretroviral, terapi kotrimoksazol, terapi antituberkulosis, dan kadar CD4. Sari Pediatri 2017;19(4):214-9

Kata kunci: hepatotoksisitas, pasien HIV anak

\section{Hepatotoxicity in Human Immunodeficiency Virus Infected Children at Hasan Sadikin Hospital Bandung}

Lidiyasiska, Adi Utomo Suardi, Anggraini Alam

Background. Abnormal liver function was the most common problem in HIV patients. Most HIV patients with liver disorders show no symptoms so liver disorders are known during liver enzyme tests.

Objective. To determine prevalence and factors that influence hepatotoxicity among HIV infected children at Hasan Sadikin Hospital Bandung.

Methods. The design of this study was descriptive analytic cross-sectional. A total of 52 HIV children were studied. Demographic and anthropometry data were taken. Blood specimen was collected to determine SGOT, SGPT with spectrophotometry UV with pyridoxal-5-phosphate method and CD4 count with flow cytometry method. The data obtained were then analyzed by chi square, Fisher exact and Mann Whitney test.

Results. The mean ages of patients were $8.2 \pm 3.5$ years. Twenty eight patients were males. Median level of SGOT was 28 U/L (15-49 U/L) and median level of SGPT was $21 \mathrm{U} / \mathrm{L}$ (6-47 U/L). Seven patients (14\%) had elevated mild liver enzyme abnormalities with one of biomarker 1,25-2,5 upper limit of normal. Factors related to hepatotoxicity did not differ significantly.

Conclusions. Prevalence of hepatotoxicity was $14 \%$ among HIV children. There was no association of hepatotoxicity with duration of antiretroviral therapy, clinical stage, antituberculosis therapy, cotrimoxazole therapy, types of antiretroviral and CD4 count. Sari Pediatri 2017;19(4):214-9

Keywords: hepatotoxicity, HIV infected children

Alamat korespondensi: Lidiyasiska, dr. Departemen Ilmu Kesehatan Anak Fakultas Kedokteran UNPAD Rumah Sakit Dr. Hasan Sadikin Bandung Jl. Pasteur no. 38 Bandung, Indonesia 40163. Email: lidiyasiska@gmail.com 
$\mathrm{J}$ umlah kasus human immunodeficiency virus (HIV) terus mengalami peningkatan. Gangguan hati merupakan masalah pada kasus HIV, terutama di negara berpenghasilan tinggi dengan angka gsungan hidup yang tinggi. Sebuah penelitian mengenai efek samping obat anti-HIV melaporkan bahwa kematian karena gangguan hati merupakan penyebab yang paling umum ditemukan. ${ }^{1}$

Risiko penyakit acquired immune deficiency syndrome (AIDS) menurun setelah diterapkan terapi antiretroviral. Risiko ini berganti dengan komplikasi jangka panjang lain yang meningkatkan morbiditas dan mortalitas, salah satunya adalah gangguan hati. Hal ini perlu menjadi perhatian khusus karena sebagian besar anak HIV dimulai dengan regimen non-nucleoside reverse transcriptase yang bersifat hepatotoksik..$^{2,3}$

Gangguan hati merupakan salah satu efek samping terapi antiretroviral pada pasien HIV. Hepatotoksitas pada pasien HIV yang mendapat terapi antiretroviral dilaporkan 6\%-30\%. ${ }^{4}$ Beberapa penelitian telah dilakukan untuk mengetahui hepatotoksisitas pada anak dengan HIV. Penelitian di Myanmar terhadap 68 pasien anak dengan HIV ditemukan 26,5\% terdapat hepatotoksisitas. Sebagian besar merupakan hepatotoksisitas derajat ringan. ${ }^{5}$

Spektrum gangguan hati pada pasien HIV bervariasi. Sebagian besar pasien HIV dengan gangguan hati tidak menunjukkan gejala sehingga gangguan hati baru diketahui saat pemeriksaan enzim hati. ${ }^{6}$

Berdasarkan hal tersebut penulis melakukan penelitian untuk mengetahui prevalensi dan faktor yang berhubungan dengan hepatotoksitas pada anak pasien HIV.

\section{Metode}

Penelitian deskripif analitik dengan rancangan cross sectional pada pasien anak berusia kurang dari 18 tahun yang telah didiagnosis HIV di Rumah Sakit Dr. Hasan Sadikin, Bandung. Penelitian dilakukan pada bulan Juli 2017 setelah mendapat persetujuan komite etik RS Dr. Hasan Sadikin. Kriteria inklusi adalah usia $<18$ tahun dan telah didiagnosis HIV. Kriteria eksklusi adalah dari anamnesis dan pemeriksaan fisis diketahui menderita penyakit hati, misalnya hepatitis atau cytomegalovirus (CMV). Subjek penelitian berjumlah 52 orang dengan cara consecutive sampling.

Semua pasien yang memenuhi kriteria dicatat nama, jenis kelamin, usia, usia saat diagnosis, lama terapi antiretroviral, berat badan, status gizi, tinggi badan, rute transmisi, stadium klinis berdasarkan World Health Organization (WHO), derajat imunodefisiensi, terapi obat-obatan yang didapat dan jenis antiretroviral. Dilakukan pengambilan darah untuk pemeriksaan SGOT, SGPT dengan metode spektrofotometri UV dengan pyridoxal-5-phosphate dan pemeriksaan kadar CD4 dengan metode flow cytometri.

Dari data yang didapat selanjutnya dilakukan analisis untuk melihat hubungan faktor lama terapi antiretroviral, stadium klinis, derajat imunodefisiensi, jenis antiretroviral, terapi kotrimoksazol, terapi antituberkulosis, dan kadar CD4 terhadap kejadian hepatotoksisitas. Uji statistik yang digunakan yaitu $c h i$ square, Fisher exact dan Mann Whitney.

Gangguan fungsi hati dapat dilihat dari peningkatan kadar enzim hati SGOT dan SGPT. Berdasarkan kriteria AIDS clinical trial group guidelines, peningkatan kadar enzim 1,25-2,5 kali upper limit of normal (ULN) merupakan hepatotoksisitas derajat 1, 2,6-5,5 ULN hepatotoksisitas derajat 2, 5,1-10 ULN hepatotoksisitas derajat 3, dan $>10$ ULN merupakan hepatotoksisitas derajat 4 . $^{7}$

\section{Hasil}

Penelitian dilakukan pada bulan Juli 2017 terhadap pasien anak yang telah didiagnosis HIV di poliklinik Teratai Rumah Sakit Dr. Hasan Sadikin, Bandung. Karakteristik subjek penelitian tertera pada Tabel 1.

Tabel 1 memperlihatkan karakteristik subjek penelitian. Subjek penelitian berjenis kelamin laki-laki lebih banyak dibandingkan dengan perempuan (54\%). Usia rata-rata adalah 8,2 tahun dengan kelompok usia terbanyak yaitu 5-10 tahun. Usia saat terdiagnosis HIV sebagian besar kurang dari 5 tahun (73\%). Berdasarkan status gizi, $9(17 \%)$ subjek termasuk kelompok gizi kurang dan 6 (12\%) subjek gizi buruk. Stadium penyakit berdasarkan WHO pada sebagian besar subjek saat terdiagnosis, yaitu stadium IV (39\%). Derajat imunodefisiensi pasien sebagian besar tanpa imunodefisiensi (75\%), dengan rentang kadar CD4 12-1932 sel/ $\mathrm{mm}^{3}$. Nilai SGOT median pada subjek penelitian $28 \mathrm{U} / \mathrm{L}$ (15-49 U/L), sedangkan nilai SGPT median $21 \mathrm{U} / \mathrm{L}(6-47 \mathrm{U} / \mathrm{L})$.

Tabel 2 memperlihatkan dari 52 subjek penelitian, $7(14 \%)$ anak didapatkan hepatotoksisitas. Berdasarkan 
Tabel 1. Karakteristik subjek penelitian

\begin{tabular}{|c|c|}
\hline Karakteristik & $\mathrm{n}=52(\%)$ \\
\hline \multicolumn{2}{|l|}{ Jenis kelamin, n (\%) } \\
\hline Laki-laki & $28(54)$ \\
\hline Perempuan & $24(46)$ \\
\hline \multicolumn{2}{|l|}{ Usia saat ini (tahun) } \\
\hline Rerata \pm SB & $8,2 \pm 3,5$ \\
\hline \multicolumn{2}{|c|}{ Kategori usia, tahun, n (\%) } \\
\hline$<5$ & $11(21)$ \\
\hline $5-10$ & $26(50)$ \\
\hline$>10$ & $15(29)$ \\
\hline \multicolumn{2}{|c|}{ Usia saat diagnosis (tahun) } \\
\hline Rerata $\pm S B$ & $3,3 \pm 2,2$ \\
\hline \multicolumn{2}{|c|}{ Usia saat diagnosis, tahun, n (\%) } \\
\hline$<5$ & $38(73)$ \\
\hline $5-10$ & $14(27)$ \\
\hline$>10$ & - \\
\hline \multicolumn{2}{|c|}{ Lama terapi antiretroviral (tahun) } \\
\hline Median (rentang) & $4,0(0,5-12,0)$ \\
\hline \multicolumn{2}{|c|}{$\begin{array}{l}\text { Lama terapi antiretroviral, tahun, } \\
\mathrm{n},(\%)\end{array}$} \\
\hline$<5$ & $35(67)$ \\
\hline $5-10$ & $12(23)$ \\
\hline$>10$ & $5(10)$ \\
\hline \multicolumn{2}{|l|}{ Berat badan $(\mathrm{kg})$} \\
\hline Median (rentang) & $18,5(9,0-47,0)$ \\
\hline \multicolumn{2}{|l|}{ Status gizi, n (\%) } \\
\hline Baik & $37(71)$ \\
\hline Kurang & $9(17)$ \\
\hline Buruk & $6(12)$ \\
\hline \multicolumn{2}{|c|}{ Tinggi badan berdasarkan usia } \\
\hline Rerata \pm SB & $117,6 \pm 20,6$ \\
\hline \multicolumn{2}{|c|}{$\begin{array}{l}\text { Tinggi badan berdasarkan usia, } \\
\text { n (\%) }\end{array}$} \\
\hline Normal & $29(56)$ \\
\hline Stunted & $15(2)$ \\
\hline Severely stunted & $8(15)$ \\
\hline \multicolumn{2}{|l|}{ Rute transmisi, n (\%) } \\
\hline Vertikal & $52(100,0)$ \\
\hline Lain-lain & $0(0,0)$ \\
\hline \multicolumn{2}{|c|}{ Stadium klinis saat diagnosis, n (\%) } \\
\hline I & $9(17)$ \\
\hline II & $9(17)$ \\
\hline III & $14(27)$ \\
\hline IV & $20(39)$ \\
\hline \multicolumn{2}{|c|}{ Derajat imunodefisiensi, n (\%) } \\
\hline Tidak ada & $39(75)$ \\
\hline Ringan & $7(14)$ \\
\hline Sedang & $2(4)$ \\
\hline Berat & $4(8)$ \\
\hline
\end{tabular}

\begin{tabular}{|c|c|}
\hline \multicolumn{2}{|c|}{ Terapi antituberkulosis, n (\%) } \\
\hline $\mathrm{Ya}$ & $2(4)$ \\
\hline Tidak & $50(96)$ \\
\hline \multicolumn{2}{|c|}{ Terapi kotrimoksazol, n (\%) } \\
\hline $\mathrm{Ya}$ & $28(54)$ \\
\hline Tidak & $24(46)$ \\
\hline \multicolumn{2}{|c|}{ Terapi antijamur, n (\%) } \\
\hline $\mathrm{Ya}$ & $0(0,0)$ \\
\hline Tidak & $52(100)$ \\
\hline \multicolumn{2}{|c|}{ Jenis antiretroviral, $\mathrm{n}(\%)$} \\
\hline ZLN & $33(63)$ \\
\hline ZLE & $17(33)$ \\
\hline TLN & $2(4)$ \\
\hline \multicolumn{2}{|c|}{ CD4 absolut (sel/mm $\mathrm{mm}^{3}$} \\
\hline Median (rentang) & $860(12-1932)$ \\
\hline \multicolumn{2}{|l|}{ CD4 Persen } \\
\hline Median (rentang) & $27,7(0,34-37,83)$ \\
\hline \multicolumn{2}{|l|}{ SGOT } \\
\hline Median (rentang) & $28(15-49)$ \\
\hline \multicolumn{2}{|l|}{ SGPT } \\
\hline Median (rentang) & $21(6-47)$ \\
\hline \multicolumn{2}{|c|}{$\begin{array}{l}\text { Keterangan: } \mathrm{n}=\text { frekuensi, \%=persentase, SB=Simpang Baku } \\
\text { ZLD: Zidovudin/Lamivudin/Nevirapin, ZLE: Zidovudin/ } \\
\text { Lamivudin/Efavirenz, TLN: Tenofovir/Lamivudin/Nevirapin }\end{array}$} \\
\hline \multicolumn{2}{|c|}{ Tabel 2. Kejadian hepatotoksisitas } \\
\hline Hepatotoksisitas & Jumlah n (\%) \\
\hline Ya & $7(14)$ \\
\hline Derajat 1 & $7(14)$ \\
\hline Derajat II & - \\
\hline Derajat III & - \\
\hline Derajat IV & - \\
\hline Tidak & $45(86)$ \\
\hline
\end{tabular}

Keterangan: $\mathrm{n}=$ frekuensi, $\%=$ persentase

derajat keparahan gangguan hati, 7 (100\%) pasien dengan hepatotoksisitas tergolong hepatotoksisitas derajat 1 . Tidak didapatkan subjek penelitian dengan hepatotoksisitas derajat 2, 3, dan 4. Angka kejadian hepatotoksisitas pada pasien HIV anak 14\%.

- Data kategorik disajikan dalam frekuensi dan persentase.

- Data numerik dilakukan uji normalitas menggunakan Kolmogorov smirnov. Untuk data berdistribusi normal disajikan dalam Mean \pm SD, untuk data tidak berdistribusi normal dalam median (rentang).

- Uji komparatif kategorik menggunakan uji chi square atau Fisher exact jika syarat chi square tidak 
Tabel 3. Kejadian hepatotoksisitas berdasarkan faktor lama terapi antiretroviral, stadium klinis, derajat imunodefisiensi, jenis antiretroviral, terapi kotrimoksazol, dan kadar CD4

\begin{tabular}{|c|c|c|c|c|}
\hline \multirow[t]{2}{*}{ Karakteristik } & \multirow[t]{2}{*}{$\mathrm{N}$} & \multicolumn{2}{|c|}{ Hepatotoksisitas } & \multirow[t]{2}{*}{$\mathrm{p}$} \\
\hline & & $\begin{array}{c}\mathrm{Ya} \\
\mathrm{n}=7\end{array}$ & $\begin{array}{l}\text { Tidak } \\
\mathrm{n}=45\end{array}$ & \\
\hline $\begin{array}{l}\text { Lama terapi antiretroviral (tahun) } \\
\text { Median (rentang) }\end{array}$ & & $3,8(1,8-6,8)$ & $3,9(0,5-12,0)$ & 0,717 \\
\hline \multicolumn{5}{|c|}{ Kategori lama terapi antiretroviral, n (\%) } \\
\hline$<5$ tahun & 35 & 6 & 29 & \\
\hline 5-10 tahun & 12 & 1 & 11 & 0,483 \\
\hline$>10$ tahun & 5 & 0 & 5 & \\
\hline \multicolumn{5}{|c|}{ Stadium klinis (WHO) saat diagnosis, n (\%) } \\
\hline I & 9 & 1 & 8 & \\
\hline II & 9 & 2 & 7 & 0,453 \\
\hline III & 14 & 3 & 11 & \\
\hline IV & 20 & 1 & 19 & \\
\hline \multicolumn{5}{|l|}{ Derajat imunodefisiensi, $\mathrm{n}(\%)$} \\
\hline Tidak ada & 39 & 6 & 33 & 0,576 \\
\hline Ringan & 7 & 0 & 7 & \\
\hline Sedang & 2 & 0 & 2 & \\
\hline Berat & 4 & 1 & 3 & \\
\hline \multicolumn{5}{|l|}{ Jenis antiretroviral, n (\%) } \\
\hline Zidovudin/Lamivudin/Nevirapin & 33 & 4 & 29 & 0,304 \\
\hline Zidovudin/Lamivudin/Efavirenz & 17 & 2 & 15 & \\
\hline Tenofovir/Lamivudin/Nevirapin & 2 & 1 & 1 & \\
\hline \multicolumn{5}{|l|}{ Terapi kotrimoksazol, n (\%) } \\
\hline $\mathrm{Ya}$ & 28 & 4 & 24 & 1,000 \\
\hline Tidak & 24 & 3 & 21 & \\
\hline \multicolumn{5}{|l|}{ Terapi antituberkulosis, n (\%) } \\
\hline $\mathrm{Ya}$ & 2 & 0 & 2 & 1,000 \\
\hline Tidak & 50 & 7 & 43 & \\
\hline $\begin{array}{l}\text { CD4 absolut (sel/mm } \mathrm{mm}^{3)} \\
\text { Median (rentang) }\end{array}$ & & $638(56-1425)$ & $865(12-1932)$ & 0,583 \\
\hline $\begin{array}{l}\text { CD4 persentase (\%) } \\
\text { Median (rentang) }\end{array}$ & & $22,5(2,7-31,0)$ & $28,4(0,3-37,8)$ & 0,075 \\
\hline
\end{tabular}

Keterangan: $\mathrm{n}=$ frekuensi, \%=persentase, $\mathrm{SD}=$ Standard Deviation

terpenuhi, yaitu nilai harapan $>5$.

- Uji komparatif numerik menggunakan uji t untuk data berdistribusi normal, dan uji Mann Whitney jika data tidak berdistribusi normal.

Tabel 3 memperlihatkan profil fungsi hati berdasarkan faktor lama terapi antiretroviral, stadium klinis, derajat imunodefisiensi, jenis antiretroviral, terapi kotrimoksazol, terapi antituberkulosis dan kadar CD4. Tidak terdapat hubungan bermakna antara faktor tersebut dengan kejadian hepatotoksisitas.

\section{Pembahasan}

Kami mendapatkan $14 \%$ pasien HIV anak dengan gangguan fungsi hati ringan. Bila dibandingkan dengan laporan penelitian sebelumnya di Brazil oleh Gil dkk ${ }^{4}$ lebih rendah, yaitu 19,7\% dari 152 anak dan remaja dengan HIV. Hal tersebut menunjukkan bahwa populasi ini mempunyai toleransi yang baik terhadap terapi antiretroviral. Di samping itu, faktor risiko terjadinya gangguan hati bera,t seperti hepatitis virus, infeksi oportuninistik, neoplasma, dan konsumsi 
alkohol tidak didapatkan. ${ }^{8,9}$ Penelitian lain di Myanmar oleh Tun $\mathrm{dkk}^{5}$ didapatkan hepatotoksisitas pada $26,5 \%$ dari 68 anak dengan HIV yang mendapat terapi antiretroviral, sebagian besar $(88,9 \%)$ merupakan hepatotoksisitas derajat ringan. Penelitian lain di Ethiopia ${ }^{10}$ didapatkan abnormalitas fungsi hati pada $20,1 \%$ dari 164 kasus HIV yang mendapat terapi antiretroviral. Namun, pada penelitian kami kategori subjek dengan infeksi hepatitis virus B dan C diikutsertakan dalam penelitian.

Berdasarkan derajat keparahan gangguan hati, hanya didapatkan gangguan hati ringan (derajat 1), tidak terdapat pasien dengan hepatotoksisitas derajat 2, 3, atau 4. Spektrum hepatotoksisitas pada pasien HIV bervariasi, mulai dari insufisiensi hati tanpa gejala sampai gagal hati yang mengancam nyawa. Gangguan hati derajat ringan dapat dijadikan penanda bagi klinisi untuk lebih waspada terhadap gangguan hati yang lebih berat pada pasien HIV. ${ }^{8}$

Peningkatan kadar transaminase merupakan sinyal yang sensitif untuk kerusakan hati. Pada sebagian besar kasus, peningkatan enzim hati tidak disertai dengan gejala. ${ }^{11}$ Penelitian di Uganda melaporkan risiko yang rendah hepatotoksisitas pada kasus HIV yang mendapat antiretroviral. ${ }^{12}$

Menurut penelitian terdahulu, faktor yang berhubungan dengan gangguan fungsi hati pada kasus HIV, yaitu lama terapi antiretroviral, stadium klinis, derajat imunodefisiensi, jenis antiretroviral, terapi kotrimoksazol, terapi antituberkuloisis dan kadar CD4.4,5,9,13,14 Namun, pada penelitian kami, faktor tersebut tidak berhubungan dengan kejadian hepatotoksisitas anak dengan HIV. Kemungkinan disebabkan fungsi hati pada saat awal sebelum terapi antiretroviral tidak diperiksa. Selain itu, faktor lain yang dapat memengaruhi, yaitu infeksi oportunistik (seperti CMV, mycobacterium avium complex, cryptococcus neoformans, microsporidia, pneumocystis jiroveci, bartonella henselae, histoplasma capsulatum), keganasan yang berhubungan dengan AIDS (sarkoma kaposi dan limfoma), fatty liver disease, RNA HIV yang tinggi, AIDS cholangiopathy atau acalculous cholecystitis. ${ }^{1,15}$

Keterbatasan penelitian kami adalah jumlah sampel yang sedikit serta tidak mengevaluasi fungsi hati pada saat awal sebelum terapi antiretroviral. Pemeriksaan dan pemantauan lebih lanjut untuk mengetahui etiologi terhadap subjek penelitian yang mengalami hepatotoksisitas juga tidak dilakukan.

\section{Kesimpulan}

Pada anak pasien HIV didapatkan angka kejadian gangguan fungsi hati sebesar 14\%. Derajat keparahan gangguan fungsi hati pada anak pasien HIV di Rumah Sakit Dr Hasan Sadikin Bandung merupakan gangguan hati derajat ringan. Tidak terdapat hubungan kejadian hepatotoksisitas dengan faktor lama terapi antiretroviral, stadium klinis, derajat imunodefisiensi, jenis antiretroviral, terapi kotrimoksazol, terapi antituberkulosis,, dan kadar CD4.

\section{Daftar pustaka}

1. Crane M, Iser D, Lewin SR. Human immunodeficiency virus infection and the liver. World J Hepatol 2012;4:91-8.

2. Aurpibul L, Lumbiganon P, Kolasaraksa P, Hansudewechakul R, Sa-nguanmoo P, Taeprasert P, dkk. Prevalence and incidence of liver dysfunction and assessment of biomarkers of liver disease in hiv infected asian children. Pediatr Infect Dis J 2015;34:153-8.

3. Lumbiganon KA, Aurpibul L. Survival of HIV infected children: a cohort study from the asia pasific region. J Acquir Immune Defic Syndr 2011;56:365-71.

4. Gil ACM, Lorenzeti R, Mendes GB, Morcillo AM, Toro AA, Silva MTN, dkk. Hepatotoxicity in HIV infected children and adolescents on antiretroviral therapy. Sao Paulo Med J 2007;125:205-9.

5. Tun WL, Khaing KW, Tin M. Antiretroviral therapy related hepatotoxicity in hiv infected children in integrated hiv care clinic, mandalay childrens hospital, myanmar. Clin Pediatr 2016;1:1-4.

6. Miller M, Kahraman A, Ross B, Beste M, Gerken G. Evaluation of quntitative liver function test in HIV positive patients under antiretroviral therapy. Eur J Med Res 2009;14:369-77.

7. Pol S, Lebray P, Vallet-Pichard A. HIV infection and hepatic enzyme abnormalities: intricacies of the pathogenic mechanisms. Clin Infect Dis 2004;38:S65-72.

8. Nunez M, Soriano V. Hepatotoxicity of antiretrovirals: incidence, mechanisms and management. Drug Saf 2005;28: 53-66.

9. Crum-Cianflone N, Collins G dan Medina S. Prevalence and factors associated with liver test abnormalities among human immunodeficiency virus-infected persons. Clin Gastroenterol Hepatol 2010;8:183-91.

10. Shiferaw MB, Tulu KT, Zegeye AM, Wubante AA. Liver Enzymes Abnormalities among Highly Active Antiretroviral Therapy Experienced and HAART Naive HIV-1 Infected Patients at Debre Tabor Hospital, North West Ethiopia: A 
comparative cross-sectional study. AIDS Res Treat 2016:17.

11. Bonacini M. Liver injury during highly active antiretroviral therapy: the effect of hepatitis $\mathrm{C}$ coinfection. Clin Infect Dis 2004; Suppl 2:S104-8.

12. Ocama P, Castelnuovo B, Kamya MR, Kirk D, Reynolds SJ, Kiragga A dkk. Low frequency of liver enzyme elevation in HIV-infected patients attending a large urban treatment centre in Uganda. Int J STD AIDS 2010;21:553-7.

13. Bottaro EG, Huberman MJ, Iannella MDC. Nevirapineassociated toxicity in clinical practice in Buenos Aires. Argentina J Int Assoc Physicians AIDS Care 2010;9:306-12.

14. Meyssonnier V, Costagliola D, and Caumes PE. Nevirapineassociated toxicity in niger. HIV Med 2008;9:62-3.

15. Price JC dan Thio CL. Liver disease in the HIV-infected individual. Clin Gastroenterol Hepatol 2010;8:1002-12. 